\title{
TiO2- Cul Nanoparticle /Ru Solid State Dye-Sensitize Solar Cells
}

\author{
Samer. Y. Al-Dabagh, Sudad. S. Ahmed Wasan. J. Taher
}

University of Baghdad,College of Science for women, Department of Physics. University of Baghdad / College of Science / Department of Physics.

\section{ABSTRACT}

University of Baghdad ,College of Science for women, Department of Physics

In this work solid state dye sensitized solar cell (SSDSSC) type (ITO / $\mathrm{TiO}_{2} / \mathrm{Ru} / \mathrm{Cul} / \mathrm{Ag}$ ) is fabricated. The thin films are prepared by pulse laser deposition (PLD) technique under the vacuum pressure of $3 \times 10^{-3} \mathrm{mbar}$ and annelid at $450{ }^{\circ} \mathrm{C}$. In this technique Nd:YAG laser at $1064 \mathrm{~nm}$ wavelength with $(200,500,800)$ pulsed was used. It was noticed from (I-V) characteristics of the solar cell that the photocurrent collected from the $\mathrm{TiO}_{2}$ (NP) is increase as the number of laser pulses increase. The conversion efficiency of $\mathrm{TiO}_{2}$ is increased from $2.115 \%$ up to $5.654 \%$ and for $\mathrm{Cul}$ from $1.73 \%$ to $5.19 \%$ when the number of pulses increase from 200 up to 800 .

\section{Keywords: Pulsed laser deposition, $\mathrm{TiO}_{2}$ thin films, Copper lodide thin film, Silver, Solar Cell}

\section{Council for Innovative Research}

Peer Review Research Publishing System

Journal: Journal of Advances in Chemistry

Vol. 12, No. 2

editor@cirjac.com

www.cirjac.com 


\section{1-1 INTRODUCTION}

Visible light can be converted directly to electricity by photovoltaic cell or solar cell. Most photovoltaic cells are made from a crystalline substance called silicon, one of the earth most common materials or mulitlayer with silicon . Solar cell are typically made by slicing a large crystal of silicon into wafers and putting two separate wafers with different electrical properties together, along with wires to enable electrons to travel between layers. ${ }^{[1]}$

Dye sensitized solar cell (DSSC) a third generation photovoltaic cell, represents one of the most promising of several alternatives a cost effective concept for solar to electric energy conversion that has been offered to challenge conventional silicon solar cells over the past two decades ${ }^{[2,3]}$. However, comparing with the traditional energy sources, the high costs of photovoltaic devices still limit their wide applications. The organic photovoltaic devices (OPVs) have drawn an increasing interest of the considering the great potential of low production costs. An OPV is a photovoltaic solar cell that uses organic electronics-a branch of electronics that deals with conductive organic polymers or small organic molecules for light absorption and charge transport ${ }^{[4]}$.

Dye-sensitized solar cells have numerous advantages such as cheap materials, simple manufacturing process, lightweight, and environmental-friendly technology ${ }^{[5]}$ However, liquid electrolyte based devices have not attained wide spread applications in the commercial market due to concerns of solvent leakage and corrosion problems from the iodide/triiodide redox couple. Many approaches to replace liquid electrolyte have been researched, for instance polymer electrolyte, ionic liquids, p-type semiconductors such as Cul or CuSCN and organic hole conductors ${ }^{[6]}$. Recently, the conversion efficiency of the SSDSC based on an organic hole conductor have achieved over $6 \%$ Power Conversion Efficiency (PCE). These interesting results have stimulated research on the SSDSSC ${ }^{[7]}$.

Dye-sensitized solar cells (DSSC) was extensively investigated for its low cost and high energy conversion efficiency. The high-efficiency DSSCs were first reported in 1991 by O'Regan and Grätzel with a power conversion efficiency of $7.12 \%{ }^{[8]}$.For further decrease the production cost meanwhile enhance device performance becomes the bottleneck for large scale application and commercialization of $\mathrm{DSSC}^{[0]}$.

\section{1-2 EXPERMENTAL WORK}

\section{1) Preparation of photo electrode}

In order to prepare the SSDSSC working electrode, the ITO glass was first prepared. The area of ITO glass piece used was $2.5 \mathrm{~cm} \times 2.5 \mathrm{~cm}$. A multi-meter was used to test the resistively of the conductive sides of each glass plate. The conductive sides of the glass plates were masked from four parallel edges with scotch tape to control the thickness of the $\mathrm{TiO}_{2}$ film and to provide non-coated areas for electrical contact and to provide $1.5 \mathrm{~cm}^{2}$ surface area for deposition.

The $\mathrm{TiO}_{2}$ nanopowder deposition on the ITO conductive coated glass plates by PLD technique. After the nanocrystalline $\mathrm{TiO}_{2}$ layer was dried at $\mathrm{RT}$, it was fired for 2 hour at $450^{\circ} \mathrm{C}$ in a furnace.

\section{2) Preparation of dye solution and sensitization (Ruthenium Dye).}

Di-tetrabutylammoniumcis-bis(isothiocyanato)bis(2,2'-bipyridyl-4,4'- dicarboxylato) ruthenium(II) also commonly known as the N719 dye, utilized is available commercially from (sigma-aldrich, product of USA). Ruthenium Dye solution has been prepared with concentration $2 \mathrm{mM}$ in $1: 1$ absolute methyl alcohol (methanol) results in good sensitization performance. 


\section{3) Preparation of hole transport material (Cul)}

After $\mathrm{TiO}_{2}$ deposited on ITO by PLD. The film is immersed in the prepared dye as mention in step three, for 24 hours at room temperature. Then Cul is deposited on the film after remove from the dye. Finally the $\mathrm{Ag}$ is deposited on the Cul and considered the final steps preparation of the solar cell. The construction of SSDSSC is shown in figure (1).

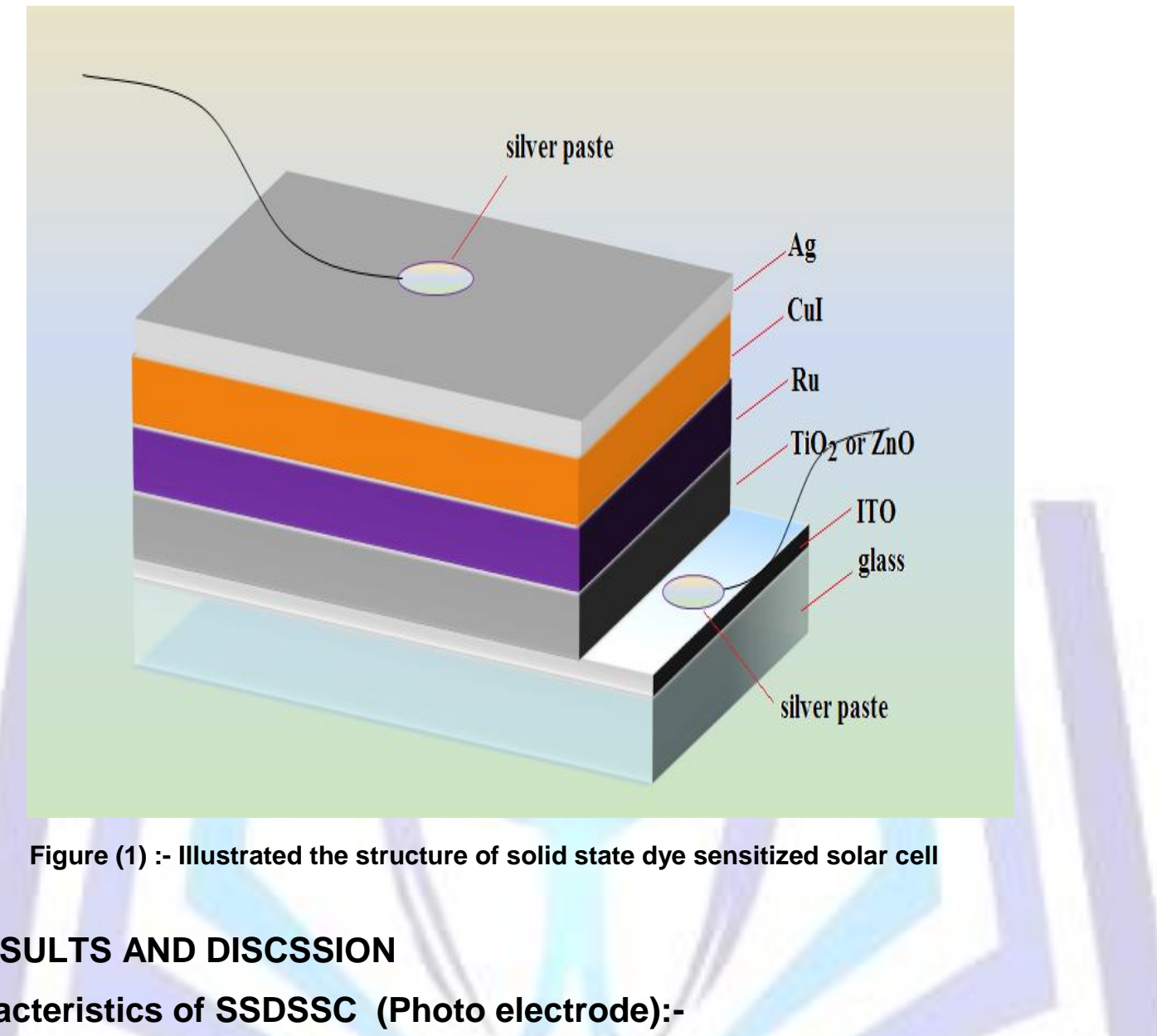

\section{1-3 RESULTS AND DISCSSION \\ I-V Characteristics of SSDSSC (Photo electrode):-}

Figure (2 and 3) show the dependence of photocurrent collected of the $\mathrm{TiO}_{2}$ (NP) thin film on the number of laser pulses. An increase in the number of laser pulses results increase in the photocurrent, indicating the dependence of current collection efficiency on number of laser pulses. I-v parameters of the solar cell photo electrode listed in table ( 1 and 2). It was noticed from (I-V) characteristics is measured of the SSDSSC the photocurrent collected from the $\mathrm{TiO}_{2}(\mathrm{NP})$ is increase as the number of laser pulses increase. The conversion efficiency of $\mathrm{TiO}_{2}$ is increase from $2.115 \%$ up to $5.654 \%$ and for Cul from $1.73 \%$ to $5.19 \%$ when the number of pulses increase from 200 up to 800 .

This increase in photocurrent can be attributed to the higher surface available for dye attachment and therefore to a higher number of photo generated electrons with better conversion efficiency. From these results, we found the dominating factor to improve $\mathrm{TiO}_{2}$ nanoparticles based solar cells, higher efficiencies, must be to increase number of pulse for increase absorption from the dye because increase the thickness of the $\mathrm{TiO}_{2}$ photo electrode. 

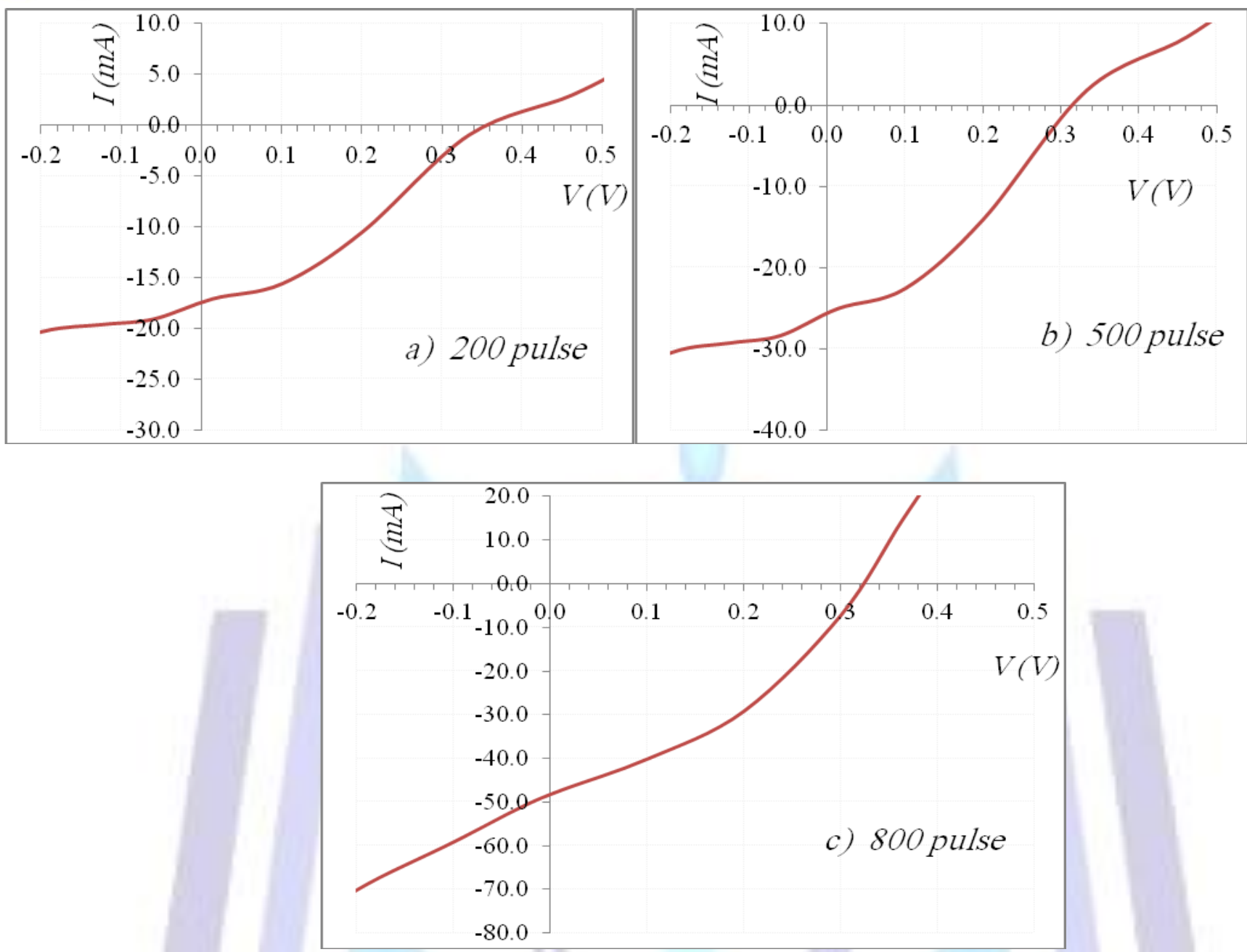

Figure (2): I-V characteristics of SSDSSC with $\mathrm{TiO}_{2}$ at different No. of Nd:YAG laser pulses $\{$ (a-200), (b500), (c-800) and Cul hole transport material kept at constant No. of pulse (800pulse ).

Table (1): Electrical properties of assembled SSDSSC at different number pulse for $\mathrm{TiO}_{2}$ thin film (ITO//TiO $/ / / N 719 / / C u l / / A g)$.

\begin{tabular}{|c|c|c|c|c|l|l|}
\hline No. of pulse & $I_{s c}$ & $\begin{array}{l}V_{o c} \\
(V)\end{array}$ & $\begin{array}{c}I_{m} \\
(m A)\end{array}$ & $\begin{array}{c}V_{m} \\
(V)\end{array}$ & $F F$ & $\eta \%$ \\
\hline 200 & 17 & 0.350 & 10 & 0.220 & 0.359 & 2.115 \\
\hline 500 & 25 & 0.315 & 15 & 0.200 & 0.381 & 2.885 \\
\hline 800 & 48 & 0.320 & 28 & 0.210 & 0.383 & 5.654 \\
\hline
\end{tabular}


ISSN 2321-807X
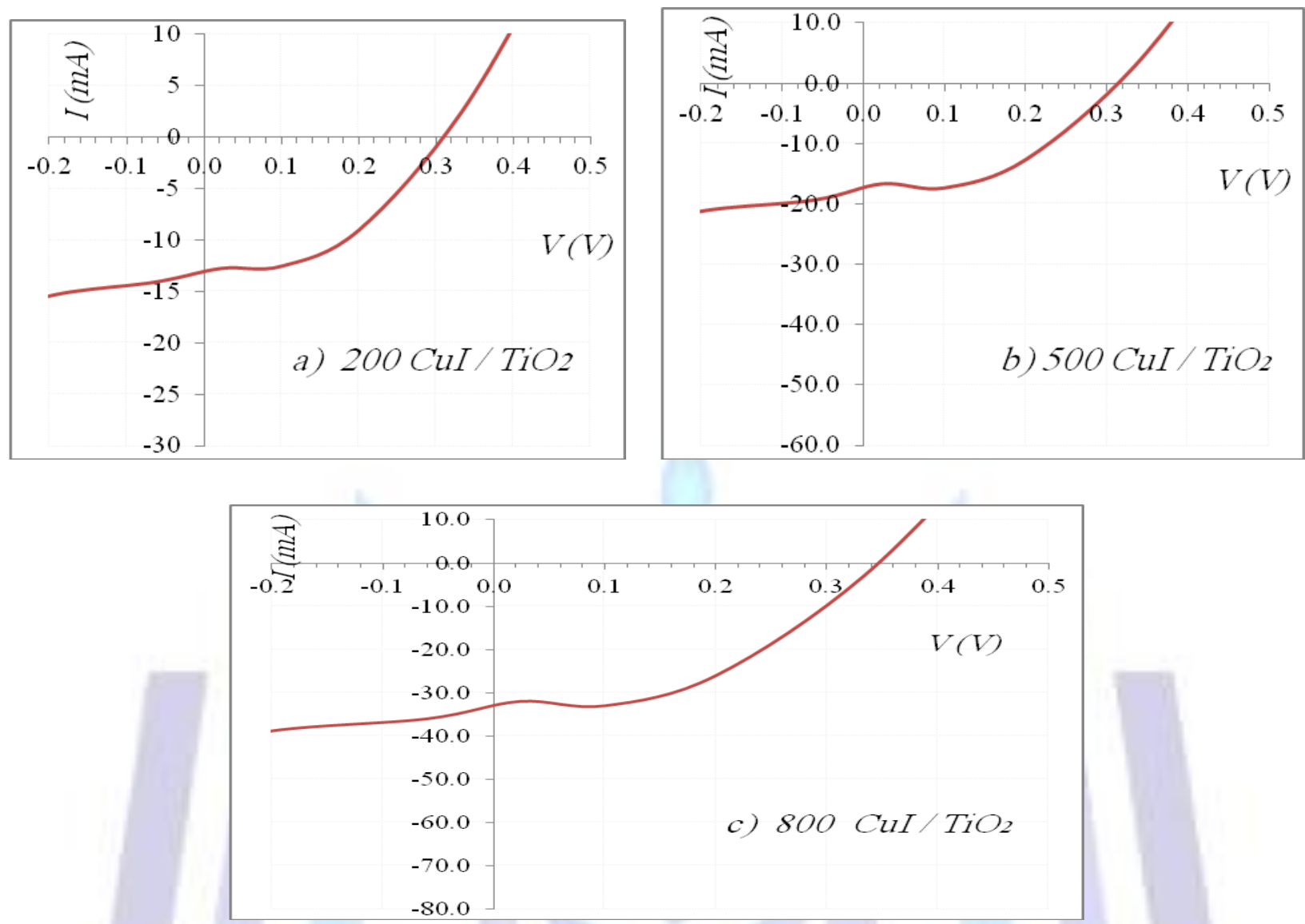

Figure (3): I-V characteristics of SSDSSC with Cul (ITO//TiO $/ / / \mathrm{N} 719 / / \mathrm{Cul} / / \mathrm{Ag})$ at different No. of Nd: YAG laser pulses $\left\{(\mathrm{a}-200),(\mathrm{b}-500),(\mathrm{c}-800)\right.$ and $\mathrm{TiO}_{2}$ photo electrode kept at constant No. of pulse (800pulse ).

Table (2): Electrical properties of assembled SSDSSC with different number of pulses for Cul thin film (ITO//TiO $/ / / \mathrm{N} 719 / / \mathrm{Cul} / / \mathrm{Ag}$ ).

\begin{tabular}{|c|c|c|c|c|l|c|}
\hline No. of pulse & $I_{s c}$ & $\begin{array}{c}V_{o c} \\
(V)\end{array}$ & $\begin{array}{c}I_{m} \\
(m A)\end{array}$ & $\begin{array}{l}V_{m} \\
(V)\end{array}$ & $F F$ & $\eta \%$ \\
\hline 200 & 13 & 0.310 & 9 & 0.200 & 0.447 & 1.731 \\
\hline 500 & 17 & 0.310 & 12 & 0.200 & 0.455 & 2.308 \\
\hline 800 & 33 & 0.350 & 27 & 0.210 & 0.468 & 5.192 \\
\hline
\end{tabular}

\section{1-4 CONCULSTION :-}

1) solar blind from $\left(\mathrm{ITO} / \mathrm{TiO}_{2} / \mathrm{Ru} / \mathrm{Cul} / \mathrm{Ag}\right)$ is fabricated. The I-V characteristics of solar cell measurement can be noted dependence of photocurrent collected from the $\mathrm{TiO}_{2}$ (NP) on the number of pulse. The increase in the number of pulses results increase in the photocurrent, indicating the dependence of current collection efficiency on number of pulse.

2) In a solid state dye-sensitized solar cell the electrolyte is replaced with a p-type semiconductor or organic hole conductor materials avoiding problems leakage of liquid electrolytes, Such as, Cul.

3) I-V parameter of the solar cell with different number of pulse for Cul thin film, can be observe the increase in the number of pulses results increase in the efficiency of solar cell. 


\section{REFERENCES:-}

1- Abood, M.A. Mustafa, F.I. Fraih, M.R. and Abduligabar, M.D. 2014 Fabrication of multi-junction solar cells. J. Baghdad for Science. 11.(Nov. 2014)614-620.

2-. Mini, P.A. 2012. Integration of nanomaterials for photovoltaic energy generation and storage Amrita Vishwavidya peetham (Nov. 2012). 1-12.

3- Würfel, P.2005_. Solar Cell Operational Principles. Physics of Solar Cells: From Principles to New Concepts, Wiley-WCH, Weinheim,

4- Walczak, M., Papadopoulou, E. M.. Sanz, Manousaki, A., Marco, J., and Castillejo M. 2009. Structural and morphological characterization of $\mathrm{TiO}_{2}$ nanostructured films grown by nanosecond pulsed laser deposition " Applied Surface Science 255 (2009)5267-5270.

5- Soman,i P., Dionigi, C., Murgia, M., Palles, D., and Ruani, N. 2005. Solid State Dye PV Cells Using Inverse Opal TiO 2 Films.solar energy material and solar cell, 87( May 2005).513-519.

6- Regan, O., Grätzel, M. 1991. A low-cost, high-efficiency solar cell based on dye-sensitized colloidal $\mathrm{TiO}_{2}$ films.j. $\mathrm{Nature}$ 353(1991) $737-740$

7- Bandara, J. and Weerasinghe, H. 2004 .Efficient solid-state dye sensitized solar cells fabricated on a compact $\mathrm{TiO}_{2}$ barrier layer preventing short-circuit current" sri lankan journal of physics. 5(2004 )27-35.

8- Jia, Lin., Jingfei, Chen., and Xianfeng, Chen. 2011.High-Efficiency Dye-Sensitized Solar Cell Based on Robust and BothEnd-Open $\mathrm{TiO}_{2}$ Nanotube Membranes. Nanoscale Research Letters.6 ( july2011) 475.

9- Wei,Z.2011. Fabrication of Dye Sensitized Solar Cells With Enhanced Energy Conversion Efficiency" Ph.D thesis.

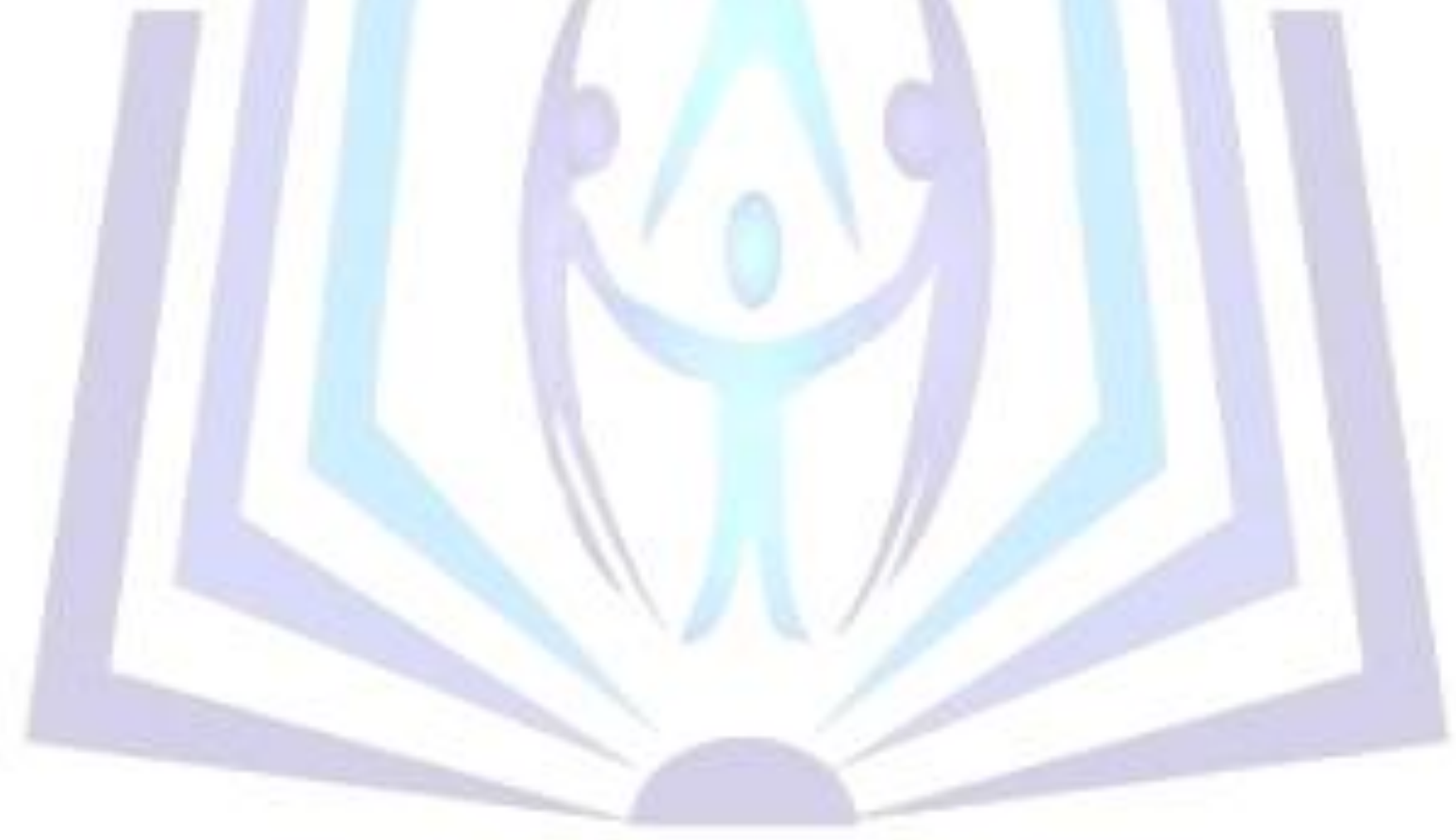

